\title{
Skull of the Pleistocene brown bear (Ursus arctos) from Yakutia, Russia
}

\author{
Gennady F. Baryshnikov \& Gennady G. Boeskorov
}

\begin{abstract}
A skull of the robust brown bear found in the mouth of Ulakhan-Orto-Stan River in the north of Yakutia has been examined. Its morphometrical characteristics referred the specimen to the subspecies $U$. arctos priscus Goldfuss, 1818 recorded in the later Middle and Late Pleistocene of Europe. This find revealed the wider distributional range for U. a. priscus, extending eastward as far as the northern part of East Siberia.
\end{abstract}

KEY-WORDS: Ursus arctos, geographical variability, Pleistocene, Siberia.

Gennady F. Baryshnikov [G_Baryshnikov@mail.ru], Zoological Institute, Russian Academy of Sciences, Universitetskaya nab. 1, Saint Petersburg 199034, Russia; Gennady G. Boeskorov, The Mammoth Museum of the Institute of Applied Ecology of the Academy of Sciences of the Sakha Republic (Yakutia), ul. Lenina, 35, Yakutsk 677007, Russia.

\section{Череп плейстоценового бурого медведя (Ursus arctos) из Якутии, Россия}

\section{Г.Ф. Барышников, Г.Г. Боескоров}

\begin{abstract}
РЕЗЮМЕ. Приведена характеристика ископаемого черепа крупного бурого медведя, найденного в устье реки Улахан-Орто-Стан на севере Якутии. Морфометрически он относится к подвиду U. arctos priscus Goldfuss, 1818, известному для второй половины среднего и для позднего плейстоцена Европы. Эта находка позволяет установить, что подвид U. a. priscus был распространен на восток до севера Восточной Сибири.
\end{abstract}

КЛЮЧЕВЫЕ СЛОВА: Ursus arctos, географическая изменчивость, плейстоцен, Сибирь.

\section{Introduction}

The brown bear (Ursus arctos L., 1758) widespread in the Holarctic forest belt was recorded in Asia beginning from the early Middle Pleistocene (Kurtén, 1968). Its fossil remains were found in numerous Siberian sites, including Yakutia (Baryshnikov \& Boeskorov, 1998). Yakutian collections predominantly comprise fragmented skulls and mandibles as well as limb bones and isolated teeth. Therefore, the recent finding of the complete calvarium of $U$. arctos in the mouth of Ulakhan-Orto-Stan River at the coast of Yana Bay seems to be especially remarkable.

The skull is kept at the collection of the Mammoth Museum, Academy of Sciences of the Sakha Republic (Yakutia) in Yakutsk (MMSR 7774). It is well preserved, not water worn, with several cracks, and without teeth (Fig. 1). The bone tissue is markedly fossilized and colored fuscous with brownish patches.

The specimen MMSR 7774 is not accompanied by any geological background. The region of the mouth of Ulakhan-Orto-Stan River is found to have the sediments of the Middle and Late Pleistocene. In particular, the fossil mammal remains of Dicrostonyx simplicior Fejfar, 1966, Mammuthus primigenius Blumenbach, 1799 (earlier form), Equus (Equus) sp. (large form), Cervalces postremus Vangengeim et Flerov, 1965, Saiga sp. associated with the Keremisitskaya Bed of the Middle
Pleistocene were recorded there (Spektor et al., 1995). These data as well as mineralization of the bone tissue and very large size of MMSR 7774 makes it possible to provisionally date the finding by the second half of the Middle Pleistocene.

For comparison, the fossil material on the brown bear from Geological-Mineralogical Museum of Kazan' University (GMMKU) and Museum of Natural History, Humboldt University, Berlin (MNHUB), together with the bear collections of Zoological Institute, Russian Academy of Sciences, St. Petersburg (ZIN) were used. A standard scheme for the skull measurements was applied (see Baryshnikov et al., 2004). The data were processed by Discriminant Analysis (forward stepwise method) from STATISTIKA 6.0 ('99 edition).

\section{Results}

Description. The MMSR 7774 specimen is characterized by a very large size (Tab. 1). The fossil brown bear exceeds recent $U$. a. arctos from Yakutia in its skull measurements, corresponding to minimum dimensions for the largest Far Eastern subspecies: U. a. beringianus Middendorff, 1851 (Amur River basin) and U. a. piscator Pucheran, 1855 (Kamchatka).

The longitudinal diameter of the alveolus of the right canine constitutes $32 \mathrm{~mm}$, its transverse diameter mea- 

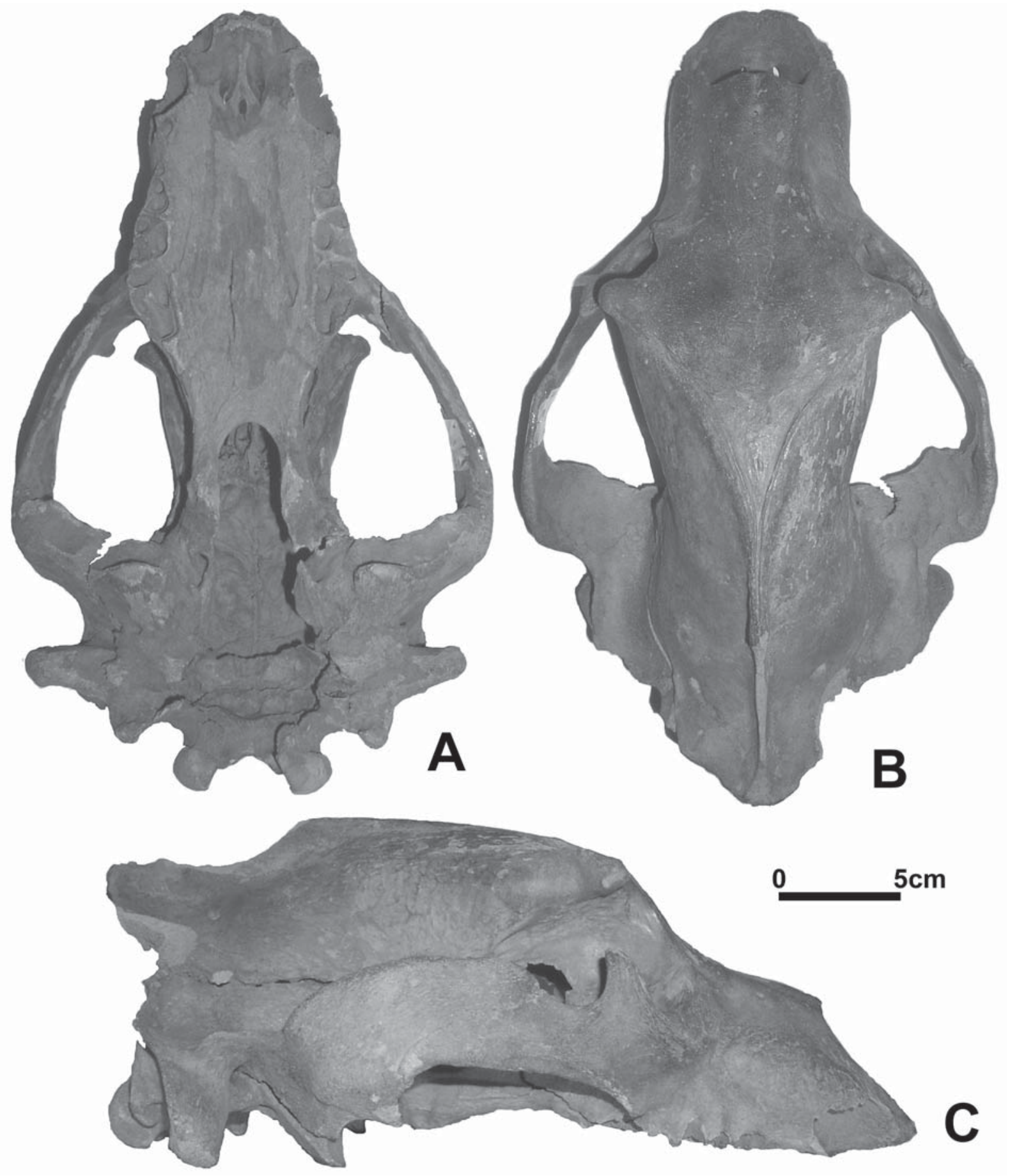

Figure 1. Skull of Ursus arctos priscus from mouth of Ulakhan-Orto-Stan River, Yakutia (MMSR 7774) in ventral (A), dorsal (B), and lateral (C) views.

suring not less than $22 \mathrm{~mm}$. Judging from the alveolus size in the upper canine and weakly expressed cranial sutures, MMSR 7774 belonged to an old male.

The skull is characterized in the moderately steep frontals; therefore the frontal profile is rather sloping. Nasal bones are long (124 mm), their anterior margins markedly extending forward of the level of P4 alveolus.
The cranial breadth between the lateral sides of the upper canines does not reach greatest palatal breadth (the greatest distance between labial margins of the upper molars). Postorbital processes are rather small, slightly directed downward, and widely spaced. The anterior orbital margin is situated above the anterior part of the M2 alveolus. The zygomatic arches are moderate- 
Table 1. Size of male skull of Ursus arctos from Pleistocene of Eurasia.

\begin{tabular}{|c|c|c|c|c|c|}
\hline \multirow{3}{*}{$\begin{array}{l}\text { Measurements, } \\
\mathrm{mm}\end{array}$} & \multicolumn{3}{|c|}{ U. a. priscus } & \multirow{2}{*}{\multicolumn{2}{|c|}{$\frac{\text { U. a. kamiensis }}{\text { Mysy, European Russia }}$}} \\
\hline & \multirow{2}{*}{$\begin{array}{c}\begin{array}{c}\text { Ulakhan-Orto-Stan } \\
\text { River, Yakutia }\end{array} \\
\text { MMSR } 7774\end{array}$} & \multirow{2}{*}{$\begin{array}{l}\begin{array}{l}\text { Zoolithenhöhle, } \\
\text { Germany }\end{array} \\
\text { MNHUB } 2680\end{array}$} & \multirow{2}{*}{$\begin{array}{c}\begin{array}{c}\text { Karmalki, } \\
\text { European Russia }\end{array} \\
\text { GMMKU } 277 / 3\end{array}$} & & \\
\hline & & & & GMMKU 279/1, lectotype & GMMKU 278/2 \\
\hline 1 & 416.0 & 406.5 & 442.0 & 462.0 & 477.0 \\
\hline 2 & 398.0 & 392.8 & 377.0 & 410.5 & 425.0 \\
\hline 3 & - & 370.5 & 355.0 & 386.5 & 394.0 \\
\hline 4 & 242.0 & 227.1 & 234.5 & 229.5 & 255.0 \\
\hline 5 & 174.0 & 208.9 & 201.0 & 223.5 & 224.3 \\
\hline 6 & 135.0 & 156.7 & 159.0 & 174.0 & 171.3 \\
\hline 7 & 210.0 & 202.8 & 198.5 & 224.5 & 230.5 \\
\hline 8 & 142.2 & 139.8 & 146.1 & 154.0 & 159.5 \\
\hline 9 & 80.8 & 75.8 & 83.0 & 85.0 & 89.0 \\
\hline 10 & 252.0 & - & 251.5 & 246.0 & - \\
\hline 11 & 114.0 & 115.0 & 116.0 & 105.0 & 129.5 \\
\hline 12 & 83.0 & 80.1 & 83.0 & 75.0 & 84.5 \\
\hline 13 & 90.7 & 82.4 & 89.5 & 84.0 & 87.8 \\
\hline 14 & 82.3 & 79.6 & 85.0 & 78.0 & 90.0 \\
\hline 15 & 219.0 & 187.0 & 203.8 & 185.0 & 221.5 \\
\hline 16 & 56.6 & 55.4 & - & - & - \\
\hline 17 & 114.7 & 107.3 & 99.0 & 101.5 & 109.0 \\
\hline 18 & 99.5 & 92.0 & 95.5 & 96.0 & - \\
\hline 19 & 57.0 & 50.0 & 51.0 & 57.0 & 58.0 \\
\hline 20 & 133.0 & 109.5 & 118.5 & 120.0 & 130.3 \\
\hline
\end{tabular}

Legend to measurements: 1 - total length, 2 - condylobasal length, 3 - basal length, 4 - upper neurocranium length, 5 facial length, 6 - "snout" length, 7 - median palatal length, 8 - length of teeth row C1-M2, 9 - length of cheek teeth row P4M2, 10 - zygomatic breadth, 11 - greatest neurocranium breadth, 12 - least breadth of skull, 13 - least breadth between the orbits, 14 - greatest breadth of the occipital condyles, 15 - greatest mastoid breadth, 16 - palatal breadth near choana, 17 greatest palatal breadth, 18 - breadth at the cabbie alveoli, 19 — greatest inner height of the orbit, 20 - skull height.

ly spaced. The single-rooted alveolus of the right $\mathrm{P} 1$ and both alveoli of P3 are present. The above mentioned features refer this skull to $U$. arctos (see Aristov \& Baryshnikov, 2001).

Comparison. The large brown bear from the Middle and Late Pleistocene of Europe is usually ascribed to the subspecies U. a. priscus Goldfuss, 1818 (Thenius, 1956; Kurtén, 1959). Judging from the basal length of the Late Pleistocene fossil skulls from Winden in Burgenland, Austria (380 mm) (Thenius, 1956), Zoolithenhöhle in Germany (370.5 mm), Murygino on Vyatka River (350 $\mathrm{mm}$ ) and Karmalki in Tatarstan, European Russia (355 mm, type of $U$. karmalkiensis; see Vereshchagin, 1959: 400, fig. 167, 2), males belonging to $U$. a. priscus were pronouncedly larger than those of the recent $U$. a. arctos.

The fossil brown bear from the early Middle Pleistocene, which is known by two calvarii from the locality of Mysy on Kama River in Tatarstan (type specimens of U. kamiensis; see Vereshchagin, 1959: 400, fig. 167, 3), was still larger. The basal length of these specimens is
$386.5 \mathrm{~mm}$ and $394 \mathrm{~mm}$ (Tab. 1). The similar proportions are observed in the extremely robust male skull found near Shegarka River in West Siberia (ZIN 32586, basal length $401.1 \mathrm{~mm}$ ), notwithstanding it being wider at the zygomatic arches $(300 \mathrm{~mm})$.

Thus, in the Europe (with exception of Mediterranean region) and West Siberia, two chronostratigraphical subspecies of $U$. arctos occur: $U$. a. kamiensis from early Middle Pleistocene and U. a. priscus (=karmalkiensis) from the late Middle Pleistocene and Late Pleistocene (Averianov et al., 1992; Baryshnikov \& Boeskorov, 1998).

The multiple discriminant function analysis based on 20 skull measurements revealed the distinct distance between the samples of $U$. a. kamiensis and $U$. $a$. priscus, as well as the separation of both fossil subspecies from $U$. a. beringianus and $U$. a. piscator (Fig. 2). The discriminant analysis placed MMSR 7774 among U. a. priscus. The later subspecies is statistically reliably differs from $U$. a. kamiensis $(\mathrm{P}<0.002)$ and from both 


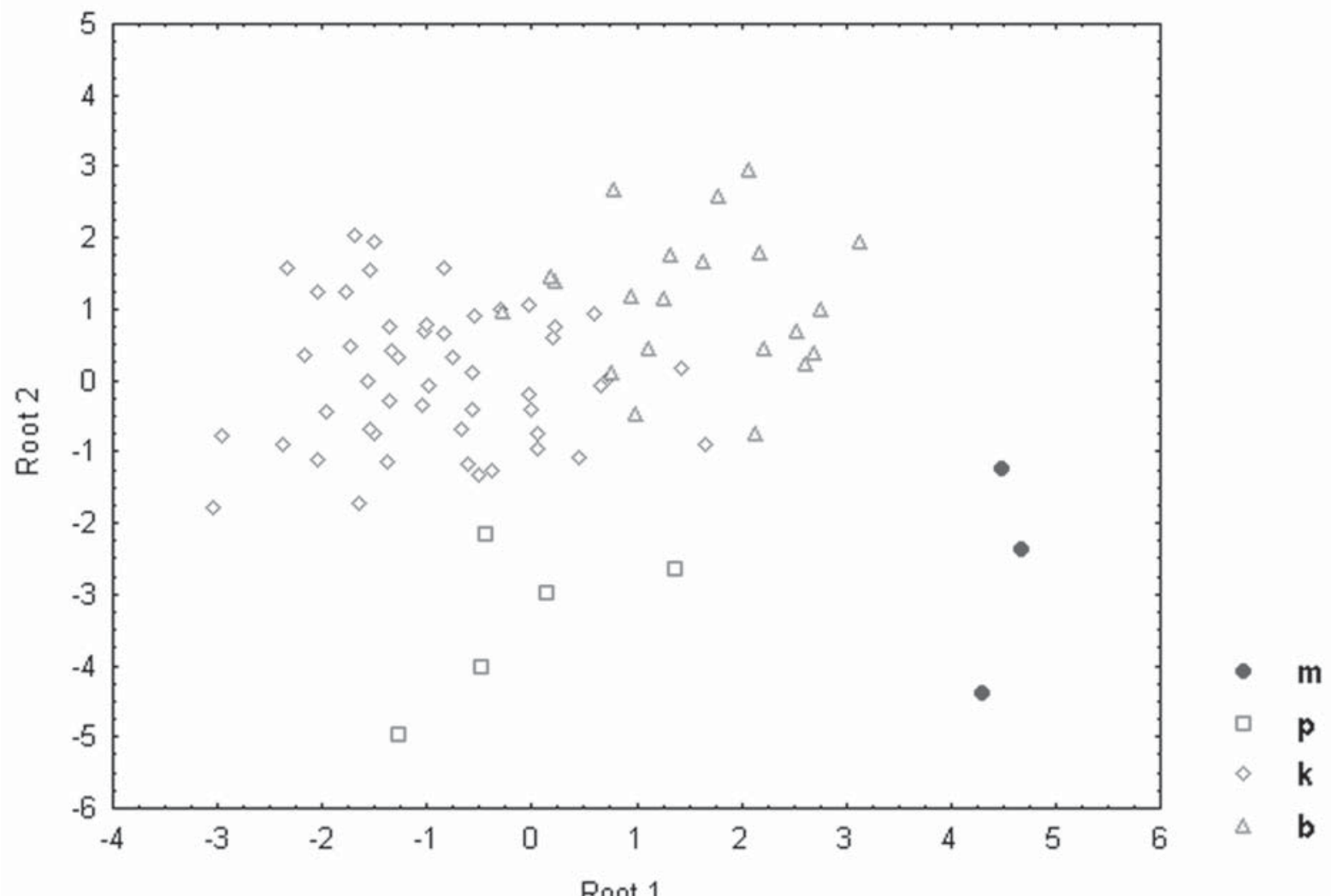

Figure 2. Plot of canonical scores for subspecies of Ursus arctos on the plane canonical variates Root 1 and Root 2 for male skull.

$\mathrm{b}$ — beringianus, Recent, $\mathrm{k}$ — piscator, Recent, $\mathrm{m}$ — kamiensis, early Middle Pleistocene, $\mathrm{p}$ — priscus, late Middle and Late Pleistocene.

recent Far Eastern subspecies $(\mathrm{P}<0.0002)$. U. a. priscus is isolated from U. a. kamiensis by the first canonical variate Root 1 , which discriminates the length of the

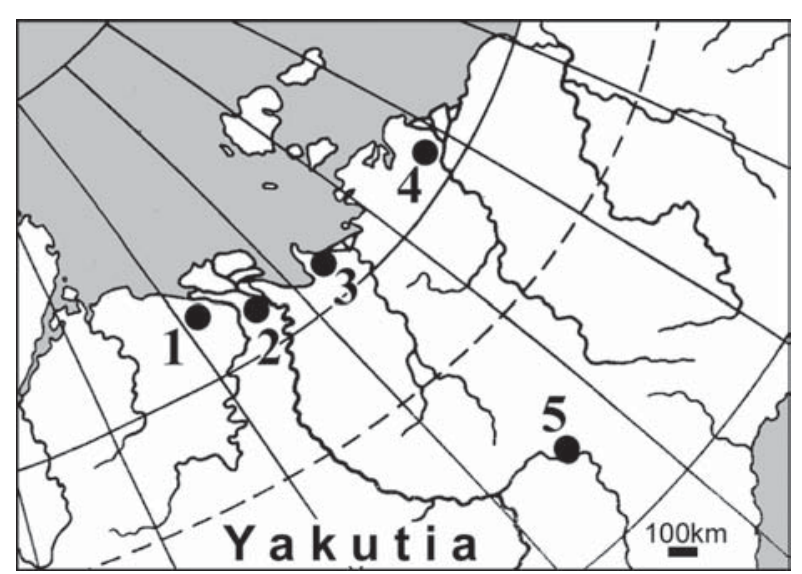

Figure 3. Map of Middle Pleistocene localities of Ursus arctos in Yakutia.

1 - Buolkalakh River, left tributary of Olenek River, skull (ZIN 29411); 2 - mouth of Lena River, maxilla (Vereshchagin, 1973); 3 - mouth of Ulakhan-Orto-Stan River, Yana Bay, skull (MMSR 7774); 4 - Taastakh Lake, Indigirka River basin, cranium fragment (Baryshnikov \& Boeskorov, 1998); 5 - Mamontova Gora, Aldan River, mandible (Rusanov, 1968). cheek tooth row $\mathrm{C} 1-\mathrm{M} 2$, length of the row $\mathrm{P} 4-\mathrm{M} 2$ palatal length, and condylobasal length (52\% of skull variation). U. a. priscus is spaced from the recent subspecies of $U$. a. beringianus/piscator by the second canonical variate Root 2, which discriminates the greatest palatal breadth, palatal length, and greatest breadth of the occipital condyles (37.2\% of skull variation).

In the ratio (in \%) between the palatal length and greatest palatal breadth, U. a. priscus (mean 189.4\%, $\mathrm{n}=4$ ) is similar to $U$. a. pruinosus Blyth, 1854 from Tibet, which demonstrate minimum ratio for recent subspecies of the brown bear. On the contrary, $U$. $a$. kamiensis (mean $214.7 \%, \mathrm{n}=3$ ), in this proportion, resembles $U$. a. beringianus from Amur River basin, which is characterized in the highest index for recent subspecies of $U$. arctos from Eurasia. However, due to scanty of the examined fossil samples, this difference seems to be not very reliable.

\section{Conclusion}

The discovery of the fossil skull of the brown bear belonging to the subspecies $U$. a. priscus, confined earlier to Europe, in the northern part of Yakutia ascertains the distribution of this subspecies throughout all Northern Eurasia. Therefore its distribution range coin- 
cides with that of the recent $U$. a. arctos, which is widespread from Scandinavia to Siberia.

Among rare finds of the brown bear fossil remains in the Middle Pleistocene of Yakutia (Fig. 3), several cranial fragments may be additionally attributed to $U$. $a$. priscus because of their large dimensions. These are two mandibles from Ulakhan Sullar (alveolar length of tooth row c1-m3: 147, $150 \mathrm{~mm}$, alveolar length of row $\mathrm{p} 4-\mathrm{m} 3$ : $82,90.7 \mathrm{~mm}$ ) and a left mandible from Kyra-Sullar (alveolar length row p4-m3 $84 \mathrm{~mm}$ ). Both these sites are situated on the Adycha River and have no direct stratigraphical data (Baryshnikov \& Boeskorov, 1998).

A smaller mandible with heavily worn teeth (length of row p4-m3 $77 \mathrm{~mm}$ ) originates from Mamontovaya Gora on Aldan River (Rusanov, 1968). Geological age of this locality was determined as the end of the Middle Pleistocene (Vangengeim, 1977). Presumably, during the Late Pleistocene, the Yakutian brown bear became smaller, especially in the Last Glaciation; the modern population from the Verkhoyanskii Range, as a result, demonstrating very small condylobasal length of the male skull (mean $308.7 \mathrm{~mm}, \mathrm{n}=15$ ), which is comparable with that dimension in the miniature white-claw brown bears from Central Asia (U. a. isabellinus Horsfield, 1826).

The diminution of $U$. arctos in size may be explained by the formation in the north of Siberia of the severe continental climate with short summer and long, frosty winter that resulted in the deforestation. The reduction of plant food supplies had led the brown bear in Yakutia to more active predating and carnivorous foraging. The successful hunting requires more mobility and endurance, which resulted in the decrease of size. In addition, smaller animals more easily accumulate necessary fat supply. The increase of proportion of the meat food, enriching with animal proteins, had been necessary for the successful overwintering. The recent brown bears inhabiting the Chukotian tundra consume more meat food than animals belonging to southern populations (Cherniavsky \& Kretchmar, 2001).

ACKNOWLEDGEMENTS. We are grateful to Dr. W.-D. Heinrich (MNHUB) and late Dr. N.L. Fomicheva (GMMKU) providing collections to study, as well as to Dr. A.O. Averianov and Dr. S.V. Baryshnikova (ZIN) for editorial improvement of the text.

\section{References}

Aristov A.A. \& Baryshnikov G.F. 2001. [The Mammals of Russia and Adjacent Territories. Carnivores and Pinnipeds]. Santkt-Peterburg: Izdatel'stvo Zoologicheskogo Instituta RAN. 560 p. [in Russian].

Averianov A.O., Baryshnikov G.F., Garutt V.E., Garutt N.V. \& Fomicheva N.L. 1992. [Volga River Fauna of Pleistocene Mammals in Geological-Mineralogical Museum of Kazan University]. Kazan': Izdatel'stvo Kazanskogo Universiteta. 164 p. [in Russian].

Baryshnikov G.F. \& Boeskorov G.F. 1998. [Brown bear Ursus arctos (Carnivora, Ursidae) from the Pleistocene of Yakutia] // Byulleten' Moskovskogo Obshchestva Ispytatelei Prirody, Otdel Biologicheskiy. T.103. No.2. P.3-9 [in Russian, with English summary].

Baryshnikov G.F., Mano T. \& Masuda R. 2004. Taxonomic differentiation of Ursus arctos (Carnivora, Ursidae) from south Okhotsk Sea islands on the basis of morphometrical analysis of skull and teeth // Russian Journal of Theriology. Vol.3. No.2. P.77-88.

Cherniavsky F.B. \& Kretchmar M.A. 2001. [Brown Bear (Ursus arctos) in North-East of Siberia]. Magadan: Izdatel'stvo Instituta biologicheskikh problem Severa RAN. 93 p. [in Russian with English summary].

Kurtén B. 1959. On the bears of the Holsteinian Interglacial // Stockholm Contribution in Geology. Vol.2. No.5.P.73102.

Kurtén B. 1968. Pleistocene Mammals of Europe. London: Weidenfeld and Nicolson. $317 \mathrm{p}$.

Rusanov B.S. 1968. [Biostratigraphy of the Cenozoic Sediments in the Southern Yakutia]. Moskva: Nauka. 460 p. [in Russian].

Spektor V.B., Epov O.G., Gabala R.O., Savchenko A.G. \& Sergeenko A.I. 1995. [Geological Map of Yakutia. Lower Yana River Block]. Yakutsk: Izdatel'stvo Geologicheskogo komiteta RS(Ya). List 17.

Thenius E. 1956. Zur Kenntnis der fossilen Braunbären (Ursidae, Mammalia) // Sitzungsberichte der mathematische-naturwissenschen Klasse, Abteilung I. Bd.165. Hf.2-3. S.153-172.

Vangengeim E.A. 1977. [Paleontological Foundation of the Anthropogene Stratigraphy of Northern Asia (on Mammals)]. Moskva: Nauka. 172 p. [in Russian].

Vereshchagin N.K. 1959. [Mammals of the Caucasus. A History of the Fauna Formation]. Moskva - Leningrad: Izdatel'stvo AN SSSR. 704 p. [in Russian].

Vereshchagin N.K. 1973. [Craniological characteristic of recent and fossil bears] // Zoologicheskii Zhurnal. T.52. No.6. P.920-930 [in Russian with English summary]. 